\title{
ANALISIS PENGARUH PARTISIPASI SANTRI KOMITMEN DAN KEMAMPUAN BERINOVASI TERHADAP KINERJA KOPERASI PONDOK PESANTREN DI KOTA SEMARANG
}

\author{
Hasyim Syarbani ${ }^{1}$
}

\begin{abstract}
In order to improve the performance of cooperative boarding lodge, then it can be done with meningkatkann participation and commitment of members, because of the participation and commitment affect the performance of the company. whereas innovation-oriented company providing a positive impact on company performance. Therefore, this study is a replication of research Johanis $W$ dominoes is applied to the cooperative boarding lodge. While the purpose of the research goal is to determine the effect of participation and ability to innovate komimen effect on the performance of cooperative boarding lodge. Based on the results show Ahwa: Turnout santri the ability to innovate cooperative commitment of the boarding lodge is still low as well as the performance cooperative boarding lodge is still low, this is indicated by a decline in business, number of members and the rest of the results of cooperative efforts boarding lodge per year. The goodness of fit indices and regression weights can be accepted research model means that the participation of santri, commitment and ability to innovate affect the performance of cooperative boarding lodge. So it can be concluded that the low performance of cooperatives that santri affected by the lack of participation, commitment and ability to innovate cooperative boarding lodge.
\end{abstract}

Keyword: participation Santri, commitment, innovation-oriented, cooperative boarding lodge

\section{PENDAHULUAN}

Dewasa ini, pertumbuhan dan penyebaran pondok pesantren sangat pesat. Dengan menjamurnya pondok pesantren yang penyuguhkan spesialisasi kajian baik tradisional ataupun modern, membawa dampak positif terhadap perkembangan ilmu pengetahuan. Data Departemen Agama menyebutkan pada 1977 jumlah pesantren sekitar 4.195 buah dengan jumlah santri 677.394 orang. Jumlah ini mengalami peningkatan pada tahun 1985, di mana pesantren berjumlah sekitar 6.239 buah dengan jumlah santri sekitar 1.084 .801 orang atau terjadi kenaikan $224 \%$ atau 9.388 buah pesantren dan $261 \%$ atau 1.770 .768 orang santri. Tahun 2002 menunjukan jumlah pesantren seluruh Indonesia sudah mencapai 11.312 buah dengan santri sebanyak 2.737 .805 orang $^{2}$.

${ }^{1}$ Dosen Jurusan Ekonomi Islam Fakultas Syari’ah IAIN Walisongo

Email: hasyim_syarbani@yahoo.co.id

2 Masyhud, H. M.Sulthon dan Moh. Khusnurdilo, Manajemen Pondok Pesantren, Jakarta: Diva Pustaka, 2003, hal 18. 
Seiring dengan perkembangan masyarakat dan arus globalisasi, pondok pesantren dituntut untuk mengadakan perubahan-perubahan secara perlahan tanpa menanggalkan ciri khasnya sebagai lembaga pendidikan agama. Perubahan-perubahan yang dilakukan pesantren salah satunya adalah pesantren dikembangkan tidak hanya mengajarkan tentang agama atau kitab kuning saja, tetapi juga pesantren dapat dikembangkan menjadi basis ekonomi kerakyatan dan pusat pengembangan ekonomi umat di daerah-daerah, baik dalam bentuk lembaga keuangan syariah atau koperasi pondok pesantren.

Di Kota Semarang terdapat 19 buah koperasi pondok pesantren 53,7\% merupakan koperasi yang aktif dan 47,3 tidak aktif. Besarnya koperasi pondok pesantren dalam status tidak aktif mengindikasikan rendahnya tingkat partisipasi anggota (santri) dan rendahnya kinerja koperasi pondok pesantren. ada beberapa faktor yang menyebabkan kinerja koperasi pondok pesantren belum optimal antara lain: koperasi pondok pesantren belum siap permasalahan dan tantangan ekonomi secara nasional, terbatasnya kemampuam manajer dalam mengelola koperasi pondok pesantren, struktur manajemen dan permodalan terbatas, terbatasnya kualitas sumber daya manusia, kurang berani menanggung resiko, tingkat motivasi bekerja masih rendah serta peranan dominan kyai (pengasuh pondok pesantren) terhadap pengelolaan koperasi pondok pesantren.. Oleh karena itu pengelolan koperasi pondok pesantren perlu mengembangkan memenajemen yang profesional sehingga diperlukan suatu penelitian yang berkaitan dengan berbagai faktor yang memiliki kontribusi terhadap keberhasilan usaha koperasi pondok pesantren antara lain partisipasi santri, komitmen dan kemampuan berinovasi anggota (santri).

Hasil penelitian Hermanto tentang partisipasi anggota koperasi pondok pesantren menunjukkan bahwa : (a) masih sebagian kecil warga pesantren yang menjadi anggota koperasi pondok pesantren, (b) partisipasi aktif para anggota kopersai pondok pesantren belum optimal, (c) sebagian kecil koperasi pondok pesantren sukses dalam usahanya dan (d) motivasi berkoperasi warga pesantren berorientasi pada kultur pondok pesantren. ${ }^{3}$ sehingga faktor partisipasi santri belum optimal dalam mengembangkan koperasi pondok pesantren.

Selain itu komitmen dan kemampuan berinovasi merupakan variabel yang mempengaruhi kinerja koperasi pondok pesantren. Penelitian Johanis W Kiuk mengatakan adanya hubungan antara komitmen dengan kinerja. ${ }^{4}$ Begitu juga penelitian Rahman, dkk mengatakan adanya hubungan antara kemampuan berinovasi dengan kinerja koperasi pondok pesantren. ${ }^{5}$ Menurut Kanter (1985) inovasi adalah perubahan yang merupakan sumber Inovasi yang dilihat sebagai peluang dari pada ancaman, sehingga diperlukan adanya proses perencanaan strategis untuk memberikan tanggapan terhadap perubahan atau inovasi masa depan dan menginterpretasikan tanda-tanda kelemahan yang ada. ${ }^{6}$ Penelitian Rahman ${ }^{7}$ menyatakan adanya hubungan antara kemempuan berinovasi dan komitmen dengan kinerja koperasi pondok pesantren. Oleh karena itu tujuan penelitian adalah (1) untuk mengetahui partisipasi santri komitmen koperasi pondok pesantren kemampuan berinovasi serta kinerja koperasi pondok pesantren (2) menemukan bukti empiris bahwa partisipasi santri, komitmen, dan kemampuan berinovasi mempengaruhi kinerja koperasi pondok pesantren. Berdasarkan

\footnotetext{
${ }^{3}$ Hermanto, Bambang, Faktor-faktor yang mempengaruhi partisipasi anggota dan hubungannya dengan keberhasilan Koperasi di Minahasa, Universitas Padjajaran, Bandung. 1991 hal 24-26.

${ }^{4}$ Kiuk, Johanis,,Kinerja Pemasaran,: Antesendens dan Konsekwensi Sebuah Model Teoritikal Dasar, Jurnal Sains Pemasaran Indonesia, Vol 5 No. 1, 2007, Hal 1-40.

5 Rahman, dkk. Analisis Komitmen orientasi pasar Dan Kemampuan Inovasi Serta pengaruhnya Terhadap Kinerja Koperasi Pondok Pesantren Di Kota Semarang, Direktorat Pendidikan Tinggi Islam, Kementerian Agama RI, Jakarta 2008, hal 49-64

${ }^{6}$ Kanters, RM, , Supporting Inovation and Venture Development in Established Compaines, Journal os Business Venturing, , September 1985, 47-60.

${ }^{7}$ Ibid,
} 
latar belakang penelitian, maka perumusan masalah penelitian adalah bagaimana pengaruh partisipasi santri, komitmen dan kemampuan berinovasi terhadap kinerja koperasi pondok persantren Kota Semarang.

\section{TELAAH TEORITIS}

\section{Koperasi Pondok Pesantren}

Koperasi sebagai lembaga atau sistem sosial dalam setiap kegiatannya berupaya untuk memberdayakan atau mengelola sumber daya tersedia unutk mencapai tingkat operasi yang efektif. Koperasi dikatakan efektif bilamana usaha koperasi dapat memberikan manfaat bagi anggotanya, Oleh karena itu perlu dukungan internal dari dalam agar tujuan koperasi tercapai. Kenyataan menunjukkan baik koperasi yang berhasil maupun koperasi yang mengalami kegagalan cenderung disebabkan oleh kerapuhan internal organisasi, Oleh karena itu koperasi perlu meningkatkan kemampuan, ketangguhan dan kemandirian agar tetap survive, kemandirian koperasi berarti menyangkut banyak aspek : aspek mental, aspek organisasi, aspek usaha dan aspek manajemen

Jadi koperasi pondok pesantren adalah pondok pesantren yang memiliki badan usaha yang berbentuk koperasi dan angota-anggotanya adalah masyarakat pesantern baik yang berada didalam pondok maupun di luar pondok. Secara organisasi koperasi pondok pesantren tidak hanya merupakan organisasi yang menggunakan sistem ekonomi sosial tetapi juga mempunyai dimensi religi yang terintergalistik dengan kegiatan-kegiatan individu (anggota) yang bertekat untuk memperbaiki situasi ekonomi dan sosial mereka, melalui usaha-usaha bersama saling membentu dan amanah yang berdasarkan akidah-akidah agama untuk kepentingan bersama. Karena dilandasi oleh suatu pemikiran bahwa hubungan antar anggota dengan subsistem koperasi yang ada maka peran hubungannya diwujudkan dalam bentuk partisipasi anggota. ${ }^{8}$

\section{Partisipasi Santri}

Menurut Choirul Djamhuri, partsisiapsi anggota merupakan kata kunci untuk menuju kesuksesan koperasi. $^{9}$ Untuk itu pengembangan usaha koperasi diarahkan untuk pengembangan peran anggota. Menurut Hanel, partisipasi anggota mempengaruhi keberhasilan koperasi. Keberhasilan kopersai dapat diukur dengan: pertumbuhan anggota, meningkatnya SHU dan meningkatnya permodalan koperasi. ${ }^{10}$ Hanel untuk menilai keberhasilan pengembangan organisasi koperasi yang dapat dijadikan tolak ukur : (1) efisien dalam pengelolaan, (2) efesien dalam pembangunan dan (3) efisien yang berorientasi pada anggota. ${ }^{11}$

Koperasi pondok pesantren sebagai badan usaha ekonomi dituntut untuk dapat mewujudkan suatu kesejahteraan ekonomi bagi pelaku-pelakunya, artinya pengurus dan badan pengawas harus mempunyai minat untuk mempergunakan kinerja pemikirannya dalam mengatasi permasalahan-permasalahan yang ada pada koperasi untuk memperkenalkan aktualisasi dan dinamisasi koperasi kepada anggota. Peran partisipasi ${ }^{12}$ aktif anggota

8 Hermanto, Bambang, Faktor-Faktor Yang Mempengaruhi Partisipasi Anggota Dan Hubungannya Dengan Keberhasilan Koperasi Di Minahasa, Universitas Padjajaran, Bandung., 1991, Hal 8

${ }^{9}$ Djamhari, Choirul, , Ke Arah Pemahaman Bangun Perusahaan Koperasi (Antologi Esai), Badan Penelitian Dan Pengembangan Koperasi , Departemen Koperasi,, 1985, hal 12

10 Amin Azis, Partisipasi Anggota Dan Pengembangan Koperasi, dalam Sri Edi Swasono (Ed) Koperasi didalam Ekonomi Indonesia, penerbit Universitas Indonesia, 1985, hal 320.

${ }^{11}$ Hanel, Alfres, Basic Aspect of Cooperative Organization and Polices for their Promotion in Developing Countries, Marburg, Bandung, 1985, hal 243.

12 Partisipasi adalah keikutsertaan, peranserta atau keterlibatan yang berkaitan dengan keadaan lahiriahnya. Pengertian ini menjelaskan peran masyarakat mengambil bagian atau turut serta menyumbangkan 
tercermin dari keterlibatan anggota dalam proses pengambilan keputusan serta berjalannya fungsi kontrol anggota terhadap roda kepengurusan organisasi.

Dari uraian tersebut menunjukkan bahwa faktor penentu terlaksananya partsipasi santri tergantung pada kemampuan atau potensi sosial dan ekonominya. Dalam penelitian Hermanto, faktor sosial yang mempengaruhi partisipasi anggota adalah (1) kepercayaan anggota terhadap pengurus, (2) adanya rasa memiliki dari anggota, (3) kesesuaian pelayanan, (3) jumlah keluarga dan (5) tingkat pendidikan. ${ }^{13}$ Dalam penelitian Muhammad menyebutkan faktor social mempengaruhi partisipasi anggota (santri) adalah (1) keterbukaan menerima ide koperasi, (2) komitmen sosial, (3) persepsi mengenai koperasi, (4) kredibilitas pengurus, (5) gaya kepemimpinan pengurus, dan (6) sistem penghargaan. Sebagai variabel bebas adalah partisipasi anggota dalam berkoperasi. ${ }^{14}$

Faktor ekonomi juga mempunyai hubungan dengan partisipasi anggota, selain faktor sosial. Potensi ekonomi yang dimiliki anggota merupakan faktor yang sangat menetukan berpartisipasi aktif. Sebagai pemiliki koperasi, anggota koperasi diminta untuk berpartsipasi dalam rangka memperkokoh permodalan melalui kegiatan penyertaaan modal yang berupa pembentukan simpanan pokok, simpanan wajib, simpanan sukarela dan pembentukan cadangan. Kemampuan finasial anggota tergantung pada kondisi ekonomi berupa pendapatan anggota. $^{15}$

\section{Komitmen}

Dalam kontek berorganisasi, komitmen didefinisikan sebagai kekuatan relatif individu dalam melibatkan dirinya dengan organisasi (Mowday dalam Boyle, 1997). Lebih lanjut Boyle mengungkapkan bahwa komitmen dapat dikarakteristikkan dalam tiga dimensi, yaitu : (1) keyakinan yang kuat akan misi dan tujuan organisasi, (2) kemauan untuk berkorban demi tujuan organisasi dan (3) Memiliki keinginan untuk membina hubungan jangka panjang dengan organisasi. Ketiga dimensi tersebut tidak hanya tampak dalam bentuk perilaku yang nyata namun juga perlu tertanam dalam perasaan. Kaitan antara efektivitas komunikasi dan komitmen terungkap dalam penelitian yang dilakukan oleh Sharma dan Patterson (1999). Dalam penelitiannya, Sharma dan Patterson (1999) mengemukakan sebuah model yang menunjukkan adanya faktor-faktor yang mempengaruhi komimen yaitu efektivitas komunikasi, kualitas fungsional, kualitas tehnik, dan kepercayaan.

\section{Kemampuan berinovasi}

Inovasi menurut Thompsons (1965) didefinisikan sebagai sesuatu yang timbul dalam melaksanakan ide-ide baru mengenai proses, produk atau pelayanan. Begitu juga yang dikemukakan oleh Zaltman, Duncan dan Nolbele's ( 1973) bahwa inovasi adalah sebagai ide, latihan atau materi yang dirasakan, sebagai unit yang relevan untuk diambil, yang dapat ditemukan dalam pelajaran organisasi. Menurut Drucker (1985) menyatakan bahwa inovasi dihasilkan dari pencarian kesempatan inovasi yang disengaja dan terfokus pada suatu obyek tertentu serta bersifat sederhana. Menurut Slater (1997) menjelaskan adanya ide-ide, gagasan, pendapat dari kegiatan inovasi yang sukses yaitu timbulnya kreativitas yang dibangun dari pasar, yang berorientasi pada budaya perusahaan. Inovasi yang dilakukan oleh organisasi

tenaga dan pikiran ke dalam suatu kegiatan, berupa keterlibatan ego atau diri sendiri atau pribadi yang lebih daripada sekedar kegiatan fisik semata. Lihat Duseldorps, D. Participation in Planned Development Influenced by Goverment of Developing Countries at Local level in Rural Areas, Agricultural University, Wageningen, 1981. hal 55

${ }_{13}$ Hermanto, Bambang, 1991, Faktor-Faktor Yang Mempengaruhi Partisipasi Anggota Dan Hubungannya Dengan Keberhasilan Koperasi Di Minahasa, Padjajaran, Bandung. Hal 11.

14 Muhammad, Jacub , 1986, Partisipasi Anggota Dan Hubungannya Dengan Pendidikan Perkoperasian, Penampilan Pengurus, Serta Sistem Penghargaan Suatu Studi Mengenai Karakteristik Dan Masalah Pembinaan Koperasi Di Lingkungan Pondok Pesantren, UPI, Bandung, hal 15.

${ }^{15}$ Ibid, hal 17. 
akan memunculkan tingkah laku-tingkah laku baru, oleh karena itu sikap atau tingkah laku yang baru menunjukan adanya kreativitas atau pengembangan yang lebih baik. Ada 4 indikator untuk mengukur kegiatan berinovasi menurut Hurley dan Hult (1998) adalah : (1) partisipasi dalam pengambilan keputusan (2) dukungan (support), (3) pengembangan diri serta (4) pembagian tugas

\section{Kinerja Koperasi Pondok Pesantren}

Kinerja adalah kemampuan kerja yang ditunjukkan dengan hasil kerja. Hawkins (The Oxford Paperback Dictionary, 1979) mengemukakan pengertian kinerja sebagai berikut: "Performance is: (1) the process or manner of performing, (2) a notable action or achievement, (3) the performing of a play or other entertainment".. Kinerja organisasi merupakan hasil yang dapat diukur dan menggambarkan kondisi empirik suatu organiisasi dari berbagai ukuran yang disepakati. Jadi kinerja koperasi pondok pesantren merupakan sesuatu yang dihasilkan oleh koperasi dalam periode tertentu dengan mengacu pada standar yang ditetapkan.). Penelitian Rahman (2008) untuk mengukur kinerja koperasi pondok pesantren dengan tiga dimensi, yaitu : (1) pertumbuhan anggota , (2) pertumbuhan serta , (3) pertumbuhan sisa hasil usaha (SHU)

Berdasarkan tinjauan pustaka dan penelitin terdahulu maka model konseptual penelitian dapat dijelaskan pada gambar 1

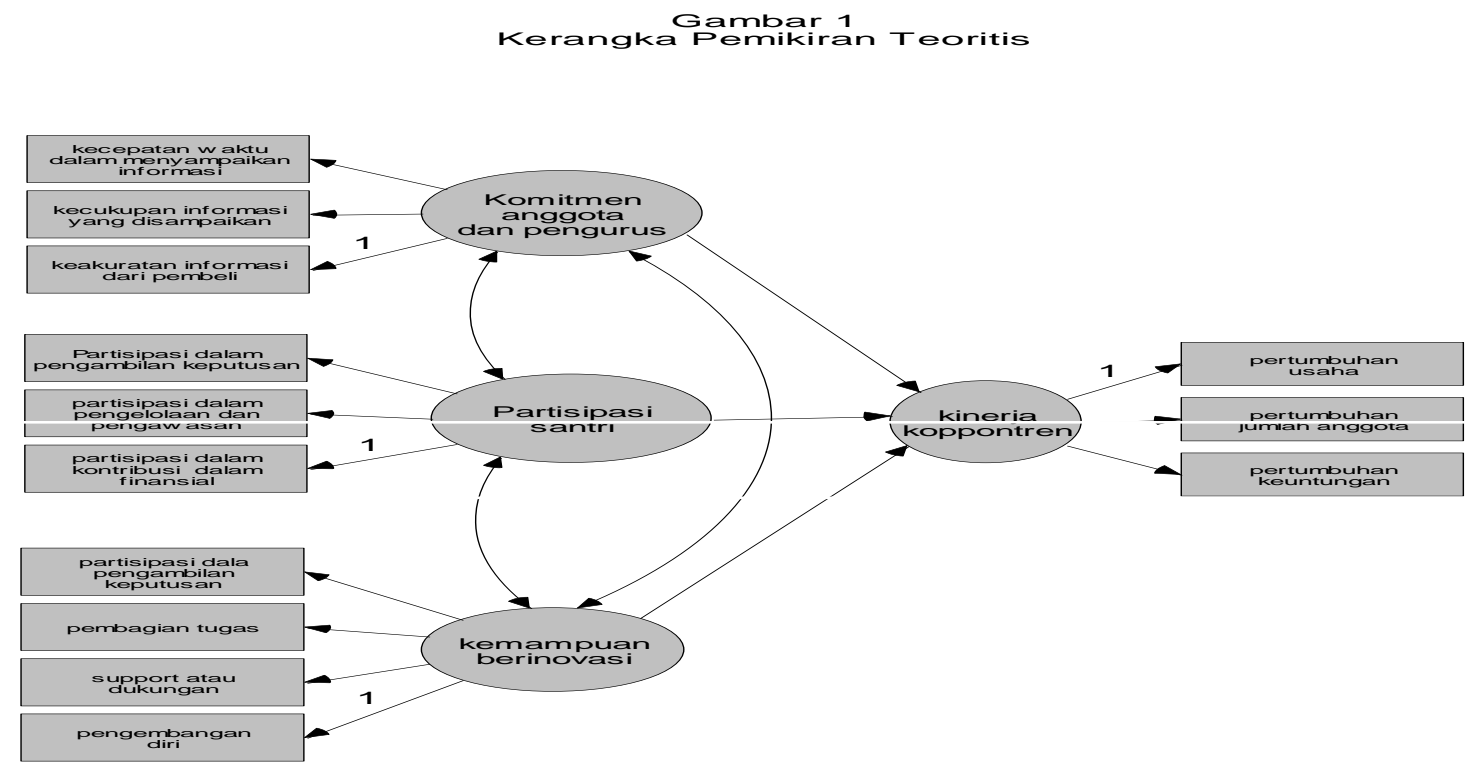

\section{METODE PENELITIAN}

Penelitian menggunakan pendekatan kuantitatif dengan tingkat eksplanatif yaitu menjelaskan hubungan sebab akibat dari sejumlah variabel penelitian dan pendekatan kualitatif. Metode Penelitian yang digunkana adalah metode survei, survei dilakukan dengan menggunakan kuesioner yang sifatnya tertutup dan terbuka, untuk kuesioner terbuka dilakukan dengan interviuw. Penelitian ini menggunakan santri sebagai anggota atau pengurus koperasi pondok pesantren secara individual sebagai unit analisis.

Secara umum pondok pesantren memiliki komponen-komponen antara lain : kiai, Ustadz santri, masjid, pondok dan kitab kuning. Dalam penelitian ini, yang menjadi fokus adalah pertama, santri atau alumni santri yang menjadi anggota koperasi pondok pesantren santri baik yang berada di pondok atau di luar pondok pesantren. Sedangkan kyai, udztadz 
atau santri yang bukan anggota koperasi pondok pesantren tidak menjadi fokus penelitian, namun dapat dijadikan informan dalam penelitian untuk klarifikasi data-data yang diperoleh dilapangan . Kedua Penelitian dilakukan pada koperasi pondok pesantren Kota Semarang yang berjumlah 19 koperasi pondok pesantren dengan jumlah anggota sebanyak 2515 orang yang menjadi populasi penelitian. Sedangkan sampel penelitian yang digunakan dengan menggunakan persamaan Rao, (1996) ${ }^{16}$

$$
\begin{array}{r}
n=\frac{N}{1+N(m o e)^{2}} \\
=\text { Jumlah sampel } \mathrm{n} \\
=\text { populasi } \mathrm{N} \\
=\text { margin of error }(\alpha=10 \%) \quad \text { Moe }
\end{array}
$$

Jadi :

$$
\begin{aligned}
n & =\frac{2515}{1+2515(0,1)^{2}} \\
n & =96,175 \text { dibulatkan } 96
\end{aligned}
$$

Jadi minimal sampel yang digunakan dalam penelitian ini adalah 96 santri. Sedangkan teknik pengambilan sampel digunakanan purposive random sampling Untuk mempermudah teknik pengambilan sampel digunakan teknik purposive random sampling, dari 19 koperasi pondok pesantren diambil 10 santri sebagai sampel sehingga dalam penelitian ini menggunakan 190 santri yang menjadi. Pengolahan data yang terkumpul dari hasil penyebaran kuesioner dari persiapan, tabulasi, dan penerapan data pada pendekatan penelitian. Selanjutnya tabulasi hasil kuesioner dengan memberikan skor sesuai dengan sistem yang telah ditetapkan yaitu menggunakan skala interval 1-5. Sedangkan untuk mengetahui pengeruh partisipasi santri, komitmen dan kemampuan berinovasi menggunakan analisis model SEM (Structural Equation Modeling) yang dioperasikan melalui program AMOS (Analysis of Moment Stucture).

\section{PEMBAHASAN}

\section{Partisipasi Santri}

Untuk mengetahui partisipasi santri dalam pengelolaan koperasi pondok pesantren, dijelaskan oleh tanggapan responden (anggota/santri) terhadap partisipasi santri dengan menggunakan 8 instrumen dapat dijelaskan pada tabel 1

Tabel 1 Tanggapan Responden Terhadap Partsispasi Santri

\begin{tabular}{|l|c|c|}
\hline \multicolumn{1}{|c|}{ Indikator } & Nilai rata-rata & $\begin{array}{c}\text { Tingkat } \\
\text { partisipasi }\end{array}$ \\
\hline Kehadiran dalam rapat anggota & 2.42 & Kurang \\
\hline Keaktifan dalam rapat rapat anggota & 2.39 & Kurang \\
\hline Keterlibatan dalam rapat anggota & 2.27 & Kurang \\
\hline Keterlibatan pengawasan koppontren & 2.22 & Kurang \\
\hline Keterlibatan pengelolaan koppontren & 2.12 & Kurang \\
\hline Keaktifan membayar iuran wajin & 2.33 & Kurang \\
\hline
\end{tabular}

${ }^{16}$ Rao, Purba (1996) Measuring Consumer Perceptions through Factor Analysis, The Asian Manager, Feb-March , 1996 Halaman 56-65 


\begin{tabular}{|l|l|l|}
\hline Keaktifan membayar iuran sukarela & 2.48 & Kurang \\
\hline Berkenan menambah modal koppontren & 2.87 & Kurang \\
\hline Rata-rata & $\mathbf{2 . 3 8}$ & Kurang \\
\hline
\end{tabular}

Sumber: data penelitian diolah

Tabel 1 menunjukkan bahwa tingkat partisipasi santri dalam koperasi pondok pesantren mempunyai rata-rata 1,58 atau dapat disimpulkan bahwa tingkat partisipasi santri dalam koperasi pondok pesantren adalah rendah. Sebagian koperasi pondok pesantren di kelola oleh pengasuh pondok pesantren (kyai dan keluarga). Sehingga peranan dominan pengasuh pondok pesantren terhadap pengelolaan dan pengawasan serta semua keputusan tentang arah pengembangan koperasi pondok pesantren ditentukan oleh keluarga kyai atau pengasuh pondok pesantren. Hal ini merupakan salah satu factor yang menyebabkan tingkat partisipasi santri dalam pengelolaan koperasi pondok pesantren rendah.

\section{Komitmen}

Untuk mengetahui komitmen koperasi pondok pesantren dalam upaya meningkatkan kinerja, dijelaskan melalui tanggapan responden (anggota/santri) terhadap komitmen pengurus koperasi pondok pesantren dalam upaya meningkatkan kinerja menggunakan 3 instrumen dapat dijelaskan pada tabel 2 .

Tabel 2 Tanggapan terhadap Komitmen Koperasi Pondok Pesantren

\begin{tabular}{|l|c|c|}
\hline \multicolumn{1}{|c|}{ Indikator } & Nilai rata-rata & $\begin{array}{c}\text { Komitmen } \\
\text { Koppontren }\end{array}$ \\
\hline $\begin{array}{l}\text { Koppontren berusaha memberi waktu yang } \\
\text { cepat dalam menyampaikan informasi pada } \\
\text { anggota }\end{array}$ & 3.01 & Cukup baik \\
\hline $\begin{array}{l}\text { Koppontren berusaha memberi informasi yang } \\
\text { cukup pada anggota }\end{array}$ & 2.98 & Kurang \\
\hline $\begin{array}{l}\text { Koppontren berusaha mencari keakuratan } \\
\text { informasi yang didapatkan dari anggota }\end{array}$ & 3.03 & Cukup \\
\hline Rata-rata & $\mathbf{3 . 0 0}$ & \\
\hline
\end{tabular}

Sumber: data penelitian diolah

Tabel 4 menunjukkan bahwa tingkat komitmen koperasi pondok pesantren mempunyai rata-rata 2,00 atau dapat disimpulkan bahwa tingkat komitmen pengurus koperasi pondok pesantren dalam upaya meningkatkan kinerja masih kurang, karena dominasi pengasuh pondok pesantren (kyai atau keluarga kyai) sehingga pengurus tidak mempunyai kekuasaan didalam pengambilan keputusan koperasi pondok pesantren. Dalam penelitian Rahman (2008) dari 130 responden menyatakan bahwa faktor rendahnya komitmen pengurus dalam upaya meningkatkan kinerja koperasi pondok pesantren adalah rendahnya motivasi pengurus $23,1 \%$, kurang adanya koordinasi antar pengurus dan anggota rendahnya pengawasan $13,8 \%$, rendahnya tingkat disiplin pengurus $12,3 \%$ dan terbatasnya kualitas SDM $10,0 \%$.

\section{Kemempuan Berinovasi}

Untuk mengetahui kemampuan berinovasi koperasi pondok pesantren dalam upaya meningkatkan kinerja, dapat dijelaskan melalui tanggapan responden (anggota/santri) terhadap kemampuan berinovasi koperasi pondok pesantren dalam upaya meningkatkan kinerja menggunakan 13 instrumen dapat dijelaskan pada tabel 3

Tabel 3 Tanggapan terhadap Kemampuan Berinovasi Koperasi Pondok Pesantren 


\begin{tabular}{|c|c|c|}
\hline Indikator & Nilai rata-rata & $\begin{array}{c}\text { Kemampuan } \\
\text { berinovasi }\end{array}$ \\
\hline Keputusan koppontren diambil secara terbuka & 2.33 & Kurang \\
\hline $\begin{array}{l}\text { Koppontren melibatkan pengurus dan anggota } \\
\text { dalam pengamblian keputusan }\end{array}$ & 2.32 & Kurang \\
\hline $\begin{array}{l}\text { Koppentren memberi kebebasan } \\
\text { mengembangkan potensi diri }\end{array}$ & 2.49 & Kurang \\
\hline $\begin{array}{l}\text { Koppontren memberi kesempatan pada } \\
\text { anggota dan pengurus dalam menumbuhkan } \\
\text { ide untuk mencapai prestasi }\end{array}$ & 2.75 & Kurang \\
\hline $\begin{array}{l}\text { Koppontren memberikan kesempatan kepada } \\
\text { anggota dan pengurus untuk ikut pendidikan } \\
\text { dan pelatihan }\end{array}$ & 2.45 & Kurang \\
\hline $\begin{array}{l}\text { Koppontren berusaha meningkatkan } \\
\text { pengetahuan anggota dan pengurus melalui } \\
\text { kursus dan pelatihan }\end{array}$ & 2.28 & Kurang \\
\hline $\begin{array}{l}\text { Manager koppontren memberi dorongan pada } \\
\text { anggota dan pengurus untuk mengembangkan } \\
\text { ide dan gagasan }\end{array}$ & 2.98 & Kurang \\
\hline $\begin{array}{l}\text { Koppontren memberi keterbukaan dalam } \\
\text { menampung ide dan gagasan }\end{array}$ & 2.69 & Kurang \\
\hline $\begin{array}{l}\text { Koppontren tanggap dan sungguh-sungguh } \\
\text { terhadap pengembangan ide dan gagasan dari } \\
\text { anggota atau pengurus }\end{array}$ & 2.77 & Kurang \\
\hline $\begin{array}{l}\text { Adanya kerjasama antar anggota dan pengurus } \\
\text { dalam koppontren }\end{array}$ & 2.67 & Kurang \\
\hline Koppontren membentuk team kerja & 2.56 & Kurang \\
\hline $\begin{array}{l}\text { Terdapat pembagian tugas atau kerja antar } \\
\text { pengurus dan anggota dalam koppontren }\end{array}$ & 2.44 & Kurang \\
\hline $\begin{array}{l}\text { Koppontren menetapkan aturan atau } \\
\text { mekanisme kerja pada pengurus dan anggota }\end{array}$ & 2.22 & Kurang \\
\hline Rata-rata & 2.53 & Kurang \\
\hline
\end{tabular}

Sumber: data penelitian diolah

Tabel 3 menunjukkan bahwa tingkat kemampuan berinovasi koperasi pondok pesantren mempunyai rata-rata 1,84 atau dapat disimpulkan bahwa tingkat kemampuan berinovasi koperasi pondok pesantren dalam upaya meningkatkan kinerja masih rendah.. Dalam penelitian Rahman (2008) faktor menurut 130 responden menyatakan bahwa yang menyebabkan kemampuan inovasi koperasi pondok pesantren masih terbatas disebabkan oleh kualitas SDM belum siap 25,6\%, sistem pengelolaan masih sederhana dan tradisional 15,3\%, usaha koperasi pondok pesantren belum mengacu pada orientasi pasar 10,7\%, koperasi pondok pesantren hanya menyediakan kebtuhan santri saja, 10,2\% serta tidak berkembangnya koperasi pondok pesantren $10,0 \%$.

\section{Kinerja Koperasi Pondok Pesantren}

Untuk mengetahui kinerja koperasi pondok pesantren menggunakan indicator perkembangan usaha, perkembangan jumlah anggota dan perkembangan sisa hasil usaha koperasi pondok pesantren dapat dijelaskan pada tabel 4,5 dan 6. 
a). Perkembangan Usaha

Tabel 4 Perkembangan Usaha Koperasi Pondok Pesantren tahun 2007 s/d 2009

\begin{tabular}{|l|c|c|c|c|}
\hline \multirow{2}{*}{ Total Unit usaha } & \multicolumn{3}{|c|}{ Tahun (dalam jutaan Rupiah) } & \multirow{2}{*}{$\begin{array}{c}\text { Rata-rata } \\
\text { pertumbuhan (\%) }\end{array}$} \\
\cline { 2 - 5 } & 2007 & 2008 & 2009 & $-7,32$ \\
\hline Jumlah & 1.244 & 1.167 & 1.062 & \\
\hline
\end{tabular}

Sumber: data Penelitian diolah

Pada tabel 4 menunjukkan bahwa selama tahun 2007 s/d 2009 terjadi penurunan yang cukup signifikan terhadap usaha koperasi pondok pesantren yang mencapai rata-rata 7,32\% per tahun atau dapat disimpulkan bahwa kinerja koperasi pondok pesantren rendah. Usaha untuk meningkatkan usaha koperasi pondok pesantren yang perlu dilakukan adalah mengembangkan orientasi pasar, memperkuat permodalan terutama modal sendiri, meningkatkan kualitas SDM, meningkatkan komitmen anggota dan pengurus, mengembangkan jenis usaha, kerjasama dengan lembaga lain, melakukan inovasi usaha serta meningkatkan partisipasi anggota (santri) menggunakan layanan pada koperasi pondok pesantren.

\section{b). Perkembangan Jumlah Anggota}

Tabel 5 Perkembangan Jumlah anggota tahun 2007 s/d 2009

\begin{tabular}{|c|c|c|c|c|}
\hline \multirow{2}{*}{$\begin{array}{c}\text { Anggota } \\
\text { Koppontren }\end{array}$} & \multicolumn{3}{|c|}{ Tahun } & \multirow{2}{*}{$\begin{array}{c}\text { Rata-rata } \\
\text { pertumbuhan }(\%)\end{array}$} \\
\hline & 2007 & 2008 & 2009 & \\
\hline Jumlah & 2.515 & 2.481 & 2.284 & $-4,59$ \\
\hline
\end{tabular}

Sumber: data penelitian diolah

Pada tabel 5 menunjukkan bahwa selama tahun 2007 s/d 2009 terjadi penurunan terhadap jumlah anggota koperasi pondok pesantren yang mencapai rata-rata $4,59 \%$ per tahun sehingga dapat disimpulkan bahwa kinerja koperasi pondok pesantren rendah. Usaha untuk meningkatkan jumlah anggota koperasi pondok pesantren yang perlu dilakukan adalah meningkatkan kesejahteraan anggota, meningkatkan kepercayaan anggota atau calon anggota, melakukan sosialisasi pentingnya berkoperasi, melakukan perubahan manajemen dalam pengelolaan dan pengawasan, laporan keuangan dan SHU yang transparan, melakukan pembinaan secara terus-meneruspada anggota maupun calon anggota, meningkatkan pelayanan pada anggota serta meningkatkan partisipasi anggota.

\section{c). Perkembangan Jumlah Sisa Hasil Usaha}

Tabel 6 Perkembangan Sisa Hasil Usaha tahun 2007 s/d 2009

\begin{tabular}{|c|c|c|c|c|}
\hline \multirow{2}{*}{ Sisa Hasil Usaha } & \multicolumn{3}{|c|}{ Tahun (dalam Ribuan Rupiah) } & \multirow{2}{*}{$\begin{array}{c}\text { Rata-rata } \\
\text { pertumbuhan (\%) }\end{array}$} \\
\cline { 2 - 4 } & 2007 & 2008 & 2009 & $-7,89$ \\
\hline Jumlah & 115,493 & 108,249 & 99,713 & \\
\hline
\end{tabular}

Sumber: data penelitian diolah

Pada tabel 6 menunjukkan bahwa selama tahun 2007 s/d 2009 terjadi penurunan yang cukup signifikan terhadap sisa hasil usaha (SHU) koperasi pondok pesantren yang mencapai rata-rata $7,89 \%$ per tahun sehingga dapat disimpulkan bahwa kinerja koperasi pondok pesantren adalah rendah. Salah satu factor adalah koperasi pondok pesantren dalam status tidak aktif (tidak melaporkan kegiatan atau ad ke dinas koperasi kota Semarang) dan bahkan ada yang tutup yaitu sekitar 5 kopoerasi pondok pesantren atau 26\% dari total koperasi pondok pesantren yang ada. Hal ini menyebabkan penurunan jumlah anggota, unit usaha dan SHU. Oleh karena itu, untuk meningkatkan kinerja koperasi pondok pesantren dengan dengan cara meningkatkan permodalan terutama modal sendiri (dari simpanan wajib dn sukarela 
anggota), meningkatkan partisipasi anggota dalam menggunakan layanan atau jasa koperasi pondok pesantren, mengembangakan jenis usaha baru yang berorientasi pasar, meningkatkan jumlah anggota baru, selalu mengikuti informasi perkembangan perkoperasian, meningkatkan profesionalitas SDM dalam mengelola unit-unit usaha, melakukan kerjasama dengan lembaga donor (bank atau pemerintah daerah) serta meningkatkan pemasaran pada unit-unit usaha teruama pada anggota dan calon anggota.

\section{Pengaruh Partisipasi Santri, Komitmen dan Kemampuan berinovasi terhadap Kinerja Koperasi Pondok Pesantren}

Untuk mengetahui pengaruh partisipasi santri, komitmen dan kemampuan berinovasi terhadap kinerja koperasi pondok pesantren digunakan analisis SEM. Berdasarkan hasil komputasi data, measurement model penelitian secara keseluruhan / full model structural equation model dapat dianalisis melalui program Amos dapat dijelaskan pada gambar 2

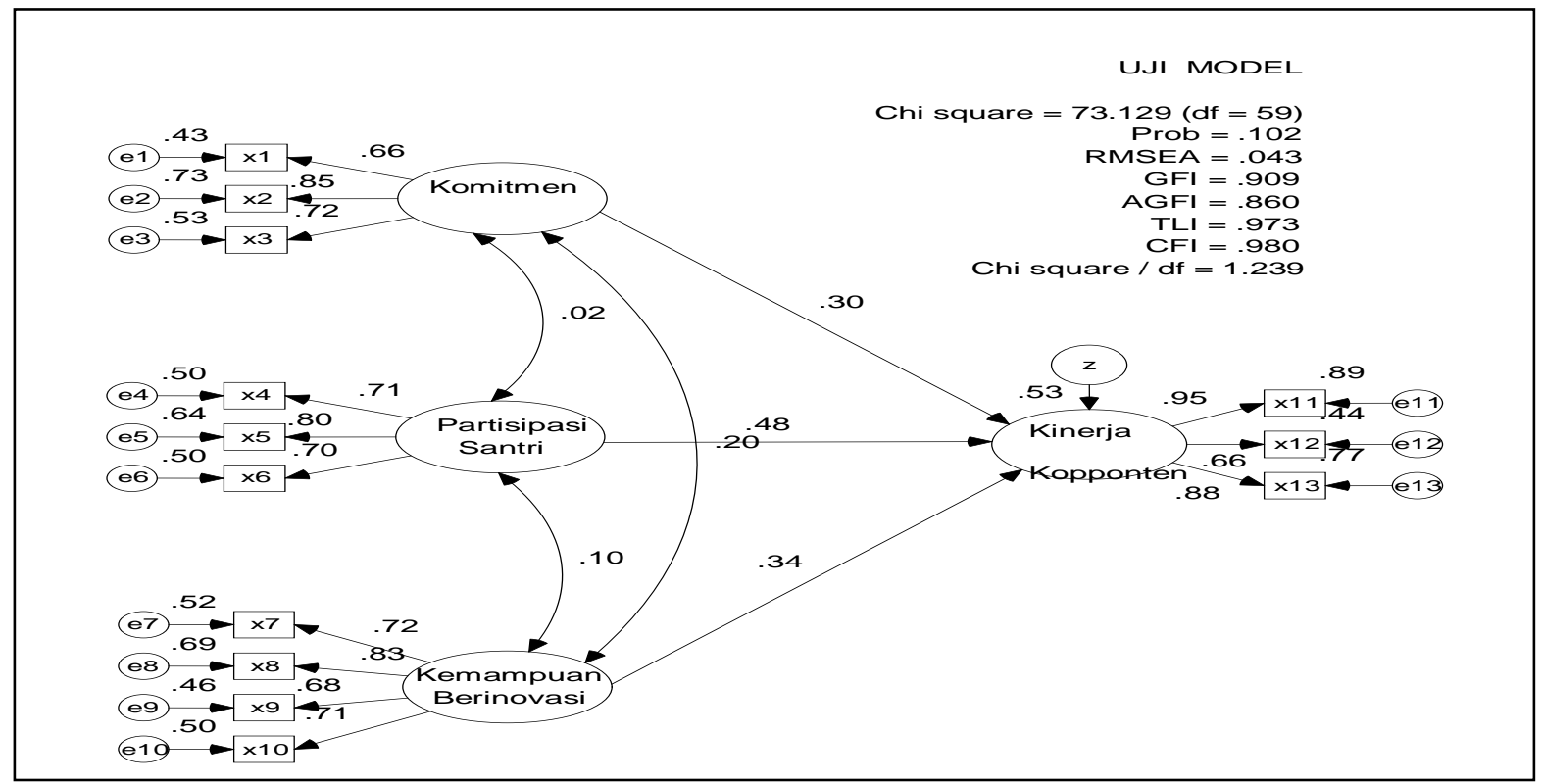

Gambar 2 Measurement Full Model Penelitian

Pada gambar 2 menunjukkan bahwa hasil evaluasi kriteria goodness of fit terhadap model penelitian dapat diterima. Untuk mengetahui pengaruh pengaruh partisipasi santri, komitmen dan kemampuan berinovasi terhadap kinerja koperasi pondok pesantren dapat dijelaskan melalui regression weigth yang dijelaskan tabel 7.

Tabel 7

Regression Weights: (Group number 1 - Default model)

\begin{tabular}{|l|l|l|l|l|l|}
\hline & & & Estimate & S.E. & C.R. \\
\hline Kinerja & <--- & Komitmen & .301 & .127 & 5.268 \\
\hline Kinerja & $<---$ & Partisipasi_Santri & .483 & .146 & 3.489 \\
\hline Kinerja & $<---$ & Kemampuan_Berinovasi & .344 & .117 & 3.892 \\
\hline x3 & $<---$ & Komitmen & 1.000 & & \\
\hline x2 & $<---$ & Komitmen & 1.308 & .174 & 7.518 \\
\hline x1 & $<---$ & Komitmen & .864 & .130 & 6.664 \\
\hline x6 & $<---$ & Partisipasi_Santri & 1.000 & & \\
\hline x5 & $<---$ & Partisipasi_Santri & 1.311 & .198 & 6.623 \\
\hline
\end{tabular}




\begin{tabular}{|l|l|l|l|l|l|}
\hline X4 & <--- & Partisipasi_Santri & 1.268 & .196 & 6.477 \\
\hline X10 & <--- & Kemampuan_Berinovasi & 1.000 & & \\
\hline X9 & $<---$ & Kemampuan_Berinovasi & .801 & .118 & 6.770 \\
\hline x8 & <--- & Kemampuan_Berinovasi & 1.042 & .133 & 7.847 \\
\hline X7 & $<---$ & Kemampuan_Berinovasi & .860 & .120 & 7.165 \\
\hline x11 & $<---$ & Kinerja & 1.000 & & \\
\hline X12 & $<---$ & Kinerja & .717 & .081 & 8.804 \\
\hline X13 & <--- & Kinerja & .927 & .067 & 13.943 \\
\hline
\end{tabular}

Sumber : data penelitian diolah

Pada tabel 7 tersebut dapat diketahui bahwa nilai CR sudah memenuhi kriteria, yaitu diatas 2 pada taraf signifikan $1 \%$ dan nilai diatas 1,96 pada taraf signifikan $5 \%(0,05)$, oleh secara regression weigth model penelitian ini dapat diterima.

Koperasi pondok pesantren adalah pondok pesantren yang memiliki badan usaha yang berbentuk koperasi dan angota-anggotanya adalah masyarakat pesantern baik yang berada didalam pondok maupun di luar pondok. Secara organisasi koperasi pondok pesantren tidak hanya merupakan organisasi yang menggunakan sistem ekonomi sosial tetapi juga mempunyai dimensi religi yang terintergalistik dengan kegiatan-kegiatan individu (anggota) yang bertekat untuk memperbaiki situasi ekonomi dan sosial mereka, melalui usaha-usaha bersama saling membentu dan amanah yang berdasarkan akidah-akidah agama untuk diharapkan menjadi pusat perekonomian umat.

Dari hasil penelitian dapat disimpulkan bahwa kinerja koperasi pondok pesantren secara finansial maupun dan non finasial sangat terbatas. Hal ini disebabkan oleh beberapa faktor antara lain : koperasi pondok pesantren belum siap melakukan inovasi, kemampuam manajemen dalam mengelola koperasi pondok pesantren kurang profesional, masyarakat kurang adaptif terhadap tuntutan perubahan, struktur manajemen dan permodalan terbatas, sumber daya manusia pengurus dan anggota terbatas, komitmen pengurus dan anggota terhadap pengembangan usaha koperasi pondok pesantren masih terbatas, pengembangan unit-unit usaha belum mengacu pada orientasi pasar, kemampuan serta rendahnya tingkat partisipasi santri terhadap pengembangan koperasi pondok pesantren. Fenomena tersebut merupakan realita yang dihadapi oleh hampir seluruh koperasi pondok pesantren yang ada di Indonesia.

Berdasarkan goodness of fit index dan regression weigth model penelitian dapat disimpulkan bahwa terdapat pengeruh partisipasi santri, komitmen dan kemampuan berinovasi terhadap kinerja koperasi pondok pesantren. Berdasarkan regression weight factor yang paling dominan yang mempengaruhi kinerja koperasi pondok pesantren adalah partisipasi santri, hal ini berarti bahwa kinerja koperasi pondok pesantren yang rendah disebabkan oleh tinggkat partisipasi santri yang rendah. oleh karena itu factor utama untuk meningkatkan kinerja koperasi pondok pesantren dengan meningkatkan peranan dan partisipasi santri dala pengelolaan koperasi pondok pesantren.

Namun demikian koperasi pondok pesantren masih memiliki potensi yang sangat besar untuk berkembang, hal ini dikarenakan: (1) terdapat 1.970 pondok pesantren dengan 418.297 santri (BPS Kota Semarang, 2008), (2) pondok pesantren bersentuhan langsung dengan kehidupan sosial keagamaan masyarakat di sekitar pesantren (3) pesantren hidup selama 24 jam sehari semalam, (4) pesantren mengakar pada masyarakat, (5) pesantren dipercaya oleh masyarakat, dan (6) pesantren merupakan lembaga pengembangan watak yang populis dan egaliter. Sehingga keberadaan koperasi pondok pesantren mempunyai nilai strategis untuk berkembang menjadi soko guru berekonomi secara santun, amanah, dan mampu memelihara ekonomi yang berdasarkan akidah-akidah ekonomi normatif dengan 
mengembangkan dimensi-dimensi : relegi, sosial dan ekonomi. Oleh itu perlu upaya meningkatkan peranan dan partisipasi santri, karena santri merupakan aset berharga yang sangat potensial dalam usaha mengembangkan koperasi pondok pesantren.

Berdasarkan perpektif ekonomi, partisipasi santri dapat meningkatkan dan memperkuat struktur permodalan koperasi pondok pesantren. Jika diasumsikan bahwa setiap santri yang berjulah 418.297 merupakan anggota koperasi yang membayar iuran wajib setiap bulannya sebesar Rp. 10.000 tiap bulan maka dalam satu tahun akan terkumpul dana (modal sendiri) mencapai Rp. 50.195.640.000 yang digunakan untuk memperkuat struktur permodalan koperasi pondok pesantren yang berdampak pada peningkatan laba atau SHU. Misalkan selama satu tahun koperasi pondok pesantren dapat menghasilakan 10 persen dari modal, maka SHU yang diterima koperasi pondok pesantren adalah Rp. 5.019.564.000, hal ini dapat meningkatkan kesejahteraan santri yang berakibat langsung maupun tidak langsung terhadap perkembangan pondok pesantren, sehingga hal ini dapat menjadikan pondok pesantren menjadi pusat perekonomian umat yang santun dan amanah yang berlandaskan akidah Islam.

Demikian juga jika 2.574 pondok pesantren yang tersebar di 36 Kabupaten dan Kota di Jawa Tengah memiliki koperasi pondok pesantren yang sehat akan berdampak pada peningkatan kesejahteraan pada masyarakat pondok dan di sekitar pondok pesantren. Sehingga akan terbentuk sentra-sentra ekonomi baru yang berpusat di pondok pesantren yang dapat menggerakkan roda perekonomian masyarakat sekitar pondok serta dapat meningkatkan perekonomian daerah maupun nasional. Hal ini merupakan satu sumbangsih pondok pesantren ikut serta berperan dalam menggerakkan perekonomian dan pembangunan bangsa

Taraf partisipasi berkoperasi para santri meningkat berkaitan erat dengan taraf keterbukaan ide, persepsinya dan komitmen sosial yang mendorongnya . Partisipasi aktif santri dalam berbagai aspeknya dipandang sangat penting bukan saja dari sisi kehidupan koperasi saja, tapi juga dari sisi peranan para santri nantinya setelah terjun kemasyarakat. Sebagai tokoh nonformal, mereka diharapkan dapat berperan sebagai motivator atau organisator koperasi dalam masyarakat yang menjadi pengikutnya. Upaya pembinaan kualitas pengurus dan anggota koperasi pondok pesantren yang telah dikembangkan tampaknya belum dapat memacu terwujudnya partisipasi santri dalam berkoperasi seperti yang diharapkan. ${ }^{17}$ Oleh karena itu peningkatan kualitas santri melalui program-program pendidikan dan pelatihan perkoperasian merupakan salah satu tumpuan untuk meningkatkan kualitas santri dalam mengembangkan koperasi pondok pesantren.

Selain partisipasi santri, komitmen dan kemampuan berinovasi merupakan faktor penentu kinerja koperasi pondok pesantren. Dalam penelitian Mowdey dalam Boyle mengatakan bahwa komitmen tidak hanya tampak dalam peribadi. Menurut Geertz etos itu ada pada kaum santri memiliki etos kerja tinggi, hal ini merupakan modal dasar santri sebagai anggota koperasi pondok pesantren memiliki komitmen yang tinggi dalam mengembangkan koperasi pondok pesantren Berdasarkan penelitian Rahman (2008) komitmen berpengaruh pada kinerja koperasi pondok pesantren. Sedangkan penelitian Zalman, Duncan \& Nolbile's (1975) menyebutkan bahwa kemempuan Inovasi berkaitan dengan keterbukaan ide dan kemampuan menemukan cara atau metode-metde baru. Kemempuan inovasi ditunjukkan dengan jiwa enterpresniurship santri dipengaruhi oleh etos kerja Islam yang hidup di lingkungan pesantren dengan bercirikan jiwa kesetiakawanan, semangat kerjasama, kejujuran serta dilandasi ketaqwaan merupakan modal dasar dalam mengembangkan usaha bersama koperasi pondok pesantren. Dalam penelitan Rahman (2008) menyimpulkan bahwa semakin tinggi berinovasi maka akan berpengaruh positif

17 Hermanto, Bambang , 1991, Faktor-Faktor Yang Mempengaruhi Partisipasi Anggota Dan Hubungannya Dengan Keberhasilan Koperasi Di Minahasa, Padjajaran, Bandung. Hal 13. 
terhadap kinerja koperasi pondok pesantren. jadi dapat disimpulkan bahwa melalui peningkatan partisipasi santri, peningkatan komitmen dan peningkatan kemampuan berinovasi dapat berpengaruh terhadap kinerja koperasi pondok pesantren.

\section{PENUTUP}

Berdasarkan hasil penelitian yang telah diperoleh melalui kajian telaah pustaka dan hasil analisis data, maka dapat disimpulkan bahwa : Tingkat partisipasi santri komitmen kemampuan berinovasi koperasi pondok pesantren masih rendah demikian juga kinerja koperasi pondok pesantren masih rendah, hal ini ditunjukkan oleh penurunan usaha, jumlah anggota dan sisa hasil usaha koperasi pondok pesantren per tahunnya. Secara goodness of fit index dan regression weight model penelitian dapat diterima artinya bahwa partisipasi santri, komitmen dan kemampuan berinovasi berpengaruh terhadap kinerja koperasi pondok pesantren. Jadi dapat disimpulkan bahwa kinerja koperasi yang rendah dipengaruhi oleh kurangnya partisipasi santri, komitmen dan kemampuan berinovasi koperasi pondok pesantren.

Namun demikian, berdasarkan kelemahan-kelamahan yang dimiliki, koperasi pondok pesantren masih memiliki potensi yang sangat besar untuk berkembang, hal ini dikarenakan: (1) terdapat 2.574 pondok pesantren dengan 418.297 santri (BPS Kota Semarang, 2008), (2) pondok pesantren bersentuhan langsung dengan kehidupan sosial keagamaan masyarakat di sekitar pesantren (3) pesantren hidup selama 24 jam sehari semalam, (4) pesantren mengakar pada masyarakat, (5) pesantren dipercaya oleh masyarakat, dan (6) pesantren merupakan lembaga pengembangan watak yang populis dan egaliter. Sehingga keberadaan koperasi pondok pesantren mempunyai nilai strategis menjadi pusat pengembangan perekonomian umat oleh karena itu diperlukan strategi pengembangan koperasi pondok pesantren melalui pemberdayaan dan peningkatan peran serta dan partisipasi santri, meningkatkan komitmen santri atau pengurus serta meningkatkan kemempuan inovasi santri dalam mengelola koperasi pondok pesantren. 


\section{DAFTAR PUSTAKA}

Amin Azis, 1985, Partisipasi Anggota Dan Pengembangan Koperasi, dalam Sri Edi Swasono (Ed) Koperasi didalam Ekonomi Indonesia, penerbit Universitas Indonesia. Jakarta.

Burhan, Umar. 1997. "Memberdayakan Ekonomi Umat : Suatu Kajian Konsepsional dalam Beberapa Bukti Empiris". Jurnal Lintasan Ekonomi. Lembaga Penerbit Fakultas Ekonomi Universitas Brawijaya, Malang.

Dhofier, Zamakhsyari. 1994. Tradisi Pesantren: Studi tentang Pandangan Hidup Kyai. LP3ES. Cet. VI, Jakarta.

Djamhari, Choirul, 1985 , Ke Arah Pemahaman Bangun Perusahaan Koperasi (Antologi Esai), Badan Penelitian Dan Pengembangan Koperasi , Departemen Koperasi. Jakarta

Duseldorps, D.1991, Participation in Planned Development Influenced by Goverment of Developing Countries at Local level in Rural Areas, Agricultural University, Wageningen.

Fadhely, Mohamad. 1995. Meneropong Kehidupan Ekonomi Umat Islam, Peradapan Islam, Kapitalis Budaya Cina di Indonesia, Penerbit Golden Press, Jakarta

Geertz, C. Geertz Clifford. 1989. Abangan Santri, Priyayi dalam Masyarakat Jawa. Terjemahan: Aswab Mahasin. Judul Asli: The Religion of Java. Pustaka Jaya. Jakarta.

Hanel, Alfres, 1985, Basic Aspect of Cooperative Organization and Polices for their Promotion in Developing Countries, Marburg, Bandung..

Hermanto, Bambang, 1991, Faktor-Faktor Yang Mempengaruhi Partisipasi Anggota Dan Hubungannya Dengan Keberhasilan Koperasi Di Minahasa, Universitas Padjajaran, Bandung.

Ismail, Munawar. 1997. "Islam Kapitalisme dan Sosialisme. Studi Komperatif Sistem Ekonomi”. Jurnal Lintasan Ekonomi, Edisi khusus Januari-April, Lembaga Penerbit FE Unibraw, Malang

Kanters, RM, 1985, Supporting Inovation and Venture Development in Established Compaines, Journal os Business Venturing, , September 47-60

Jusuf Harsono dan Slamet Santoso, 2006, Etos Kerja Pengusaha Muslim Perkotaan, Jurnal Penelitian Humaniora, Edisi Khusus, Juni 2006.

Kiuk, Johanis, 2007,Kinerja Pemasaran,: Antesendens dan Konsekwensi Sebuah Model Teoritikal Dasar, Jurnal Sains Pemasaran Indonesia, Vol 5 No. 1 Hal 1-40.

Madjid, Nurcholish. 1997. Bilik-Bilik Pesantren: Sebuah Potret Perjalanan. Penerbit Paramadina. Jakarta.

Mashuri, A. A. 2002. "Kontribusi Pesantren terhadap Perubahan Sosial Budaya Masyarakat Indonesia". Makalah disajikan pada Seminar Nasional Pengembangan IPTEK untuk Media Da'wah dan Peran Pesantren dalam Transformasi Sosial. Bandung, 23 April 2002. PT. Telkom Tbk

Masyhud, H. M.Sulthon dan Moh. Khusnurdilo, 2003. Manajemen Pondok Pesantren, Diva Pustaka, Jakarta: 
Muhammad, Jacub , 1986, Partisipasi Anggota Dan Hubungannya Dengan Pendidikan Perkoperasian, Penampilan Pengurus, Serta Sistem Penghargaan Suatu Studi Mengenai Karakteristik Dan Masalah Pembinaan Koperasi Di Lingkungan Pondok Pesantren, UPI, Bandung.

Rahman, dkk. (2008) Pengaruh Komitmen orientasi pasar Dan Kemampuan Inovasi Terhadap Kinerja Koperasi Pondok Pesantren Di Kota Semarang, Direktorat Pendidikan Tinggi Islam, Kementerian Agama RI, Jakarta.

Rao, Purba (1996) , Measuring Consumer Perceptions through Factor Analysis, The Asian Manager, Feb-March.

Ropke, Jocheb, 1989, The Economic Theory of Corporatives, University of Marburg, West Germany.

Syahyuti, (1999) Penelusuran Aspek Ekonomi Pada Pondok Pesantren Dan Peluang Pengembangannya, FAE volume 17 No. 2 Desember 1999

Usman, Sunyoto. 1998. Perkembangan dan Pemberdayaan Masyarakat.: Penerbit Pustaka Pelajar., Yogyakarta.

Wahid, Abdurrahman (2001) Menggerakkan Tradisi: esai-esai pesantren, LkiS, Yogyakarta.

Weber, Max. 2000. Etika Protestan dan Semangat Kapitalisme. Penerbit Pustaka Promethe, Jakarta

Wheelen, Thomas L., and J. David Hunger. 2002. Strategic Management and Business Policy, Eight Edition, Pearson Education, New Jersey. 